\title{
Pulp tissue inflammation and angiogenesis after pulp capping with transforming growth factor $\beta 1$
}

Sri Kunarti

Department of Conservative Dentistry

Faculty of Dentistry, Airlangga University

Surabaya - Indonesia

\begin{abstract}
In Restorative dentistry the opportunity to develop biomemitic approaches has been signalled by the possible use of various biological macromolecules in direct pulp capping reparation. The presence of growth factors in dentin matrix and the putative role indicating odontoblast differentiation during embryogenesis has led to the examination on the effect of endogenous TGF- $\beta 1$. TGF- $\beta 1$ is one of the Growth Factors that plays an important role in pulp healing. The application of exogenous TGF- $\beta 1$ in direct pulp capping treatment should be experimented in fibroblast tissue in-vivo to see the responses of inflammatory cells and development of new blood vessels. The increase in food supplies always occurs in the process of inflammation therefore the development of angiogenesis is required to fulfil the requirement. This in-vivo study done on orthodontic patients indicated for premolar extraction between 10-15 years of age. A class $V$ cavity preparation was created in the buccal aspect $1 \mathrm{~mm}$ above gingival margin to pulp exposure. The cavity was slowly irrigated with saline solution and dried using a sterile small cotton pellet. The sterile absorbable collagen membrane was applied and soaked in $5 \mu l$ TGF- $\beta 1$. It was covered by a Teflon pledge to separate from Glass Ionomer Cement restoration. Evaluation was performed on day 7; 14; and 21. All samples were histopathologycally examined and data was statistically analysed using one way ANOVA and Dunnet T3.There were no inflammatory symptoms in clinical examination on both $\mathrm{Ca}(\mathrm{OH})_{2}$ and TGF- $\beta 1$, but they increased the infiltration of inflammatory cells on histopathological examination. There were no significant differences $(p>0.05)$ between $\mathrm{Ca}(\mathrm{OH})_{2}$ and TGF- $\beta 1$ in inflammation cell and significant differences $(p<0.05)$ in angiogenesis on day 7 and 14 . There were no significant differences $(p>0.05)$ in inflammation cell with in TGF- $\beta 1$ groups and significant differences $(p<0.05)$ with in $\mathrm{Ca}(\mathrm{OH})_{2}$ groups on day 7 and 14. It is concluded TGF- $\beta 1$ functions as direct capping medication has the same inflammatory response as $\mathrm{Ca}(\mathrm{OH})_{2}$, however, TGF- $\beta 1$ developed angiogenesis earlier than $\mathrm{Ca}(\mathrm{OH})_{2}$.
\end{abstract}

Key words: calcium hydroxide, TGF- $\beta 1$, inflammation, angiogenesis

Correspondence: Sri Kunarti, c/o: Departemen Konservasi Gigi, Fakultas Kedokteran Gigi Universitas Airlangga. Jln. Mayjend. Prof. Dr. Moestopo No. 47 Surabaya 60132, Indonesia. E-mail: attybp@yahoo.com

\section{INTRODUCTION}

Homeostatis condition in human's tissue needs balanced interaction between cells and extra cellular matrix as protein supplier involving the role of various cytokines through specific receptor. Disease will consequently occur if the balance between cells and extra cellular matrix is disturbed. The improvement of damaged tissue will manifest if the body successfully maintains the homeostatic condition from the effect of harmful environment. ${ }^{1}$

Dentin perforation will initially cause several episodes such as: inflammation, synthesis of new collagen and the formation of dentinal bridge, finally, reparative dentin formation will be necessarily done. ${ }^{2,3}$ The inflammation is indicated by movement of fluid circulation, plasma protein and leukocyte to tissue responding to the presence of danger. Inflammation is essential mechanism which is required to improve structure and tissue functional disturbance as well as to defend itself from the danger such as: tissue damage, microorganism invasion and foreign body disturbing the balance interaction between cells and extra cellular matrix
(ECM). Inflammatory response completely depends on blood vessel, cell as well as fluid circulating in blood vessel. ${ }^{4}$ The initial symptom of inflammation is indicated by secretion of various mediators such as transforming growth factor- $\beta 1$ (TGF- $\beta 1$ ) followed by activation of complement, coagulation system, inflammation cell and endothelial cell. Immediately after the injury is present in dentin, it will be followed by recovery process by releasing various growth factors, cytokine and accumulative molecule from serum from blood vessel rupture and platelet degranulation. ${ }^{5}$ Inflammation cell is also the source of various growth factor which are needed to initiate proliferation phase in tissue recovery. The formation of reparative dentin is completely influenced by inflammation process, cell proliferation, cell migration, angiogenesis and production of extra cellular matrix. TGF- $\beta 1$ regulates all of the episodes including chemotaxis of inflammation cell, angiogenesis, deposition of extra cellular matrix and the formation of new tissue. ${ }^{6}$

Concentration of TGF- $\beta 1$ increases in dentin caries condition comparing to healthy dentin. TGF- $\beta 1$ in reparative dentin matrix is higher than primary dentin 
matrix. The increase of intracellular expression of TGF- $\beta 1$ and ECM in dentin carries is suspected that TGF- $\beta 1$ has an essential role to response injury and tissue recovery. ${ }^{7}$ The parameter of inflammation response in the present study is the number of inflammation cells and synthesis of new blood vessels (angiogenesis) in 7, 14 and 21 days of recovery process. The purpose of the present study was to observe the response of inflammation cell and angiogenesis of TGF- $\beta 1$ and material with calcium hydroxide $\left[\mathrm{Ca}(\mathrm{OH})_{2}\right]$ as the comparation because up to the present the material of direct pulp capping.

\section{MATERIALS AND METHODS}

The study was done on orthodontic patients indicated for premolar extraction. Anaesthesia in buccal fold region was done using $0.6 \mathrm{ml}$ xylestesin F. Rubber dam, and saliva ejector were aplied. Alcohol $70 \%$ were used to disinfect the preparation at buccocervical. Preparation of the cavity on $1 \mathrm{~mm}$ buccal site above gingival margin, completed by intermittent bur with light pressure. Preparation was done declining toward apical using no. 3 round bur in $1.5 \mathrm{~mm}$ diameter almost reaching the pulp, then no. 1 round bur in $0.5 \mathrm{~mm}$ diameter was used to penetrate thin dentin layer reaching perforation in pulpa coronalis. Slow irrigation using $0.5 \mathrm{ml}$ saline solution was performed in cavity region and dried by sterile cotton pellet. Visible light of $\mathrm{Ca}(\mathrm{OH})_{2}$ in tube (calcimol) was applied $1 \mathrm{~mm}$ on pulp for 40 seconds. In other groups, $20 \mathrm{ng} / \mathrm{ml}$ TGF- $\beta 1$ caried by material collagen membrane ${ }^{3}$ was applied and completed by filling material of glass ionomer cement type 2 . Teflon pledged $^{8}$ was given to avoid the possible reaction between glass ionomer cement type 2 and material of pulp capping. Then extraction was classified into 3 extraction timing on day 7, 14 and 21 direct pulp capping. The preparation of histological preparat was began since the initial process of extraction. Fixation using 10\% formalin buffer for 48 hours followed by decalcification using $\mathrm{AlCl}$, formic acid, $37 \% \mathrm{HCl}$ and aquadest continued by dehydration process to extract the water from the tissue and substituted by hardening media (paraffin) and clearance was done using xylene.

After paraffin hardening, the tissue could be cut using microtome in $4 \mu \mathrm{m}$ thickness. The next step, hematoxylin and eosin were stained on the resulting preparat. Light microscope in 400 times magnification was used to count the number of inflammation cell (Figure 1) and blood vessel (Figure 2).

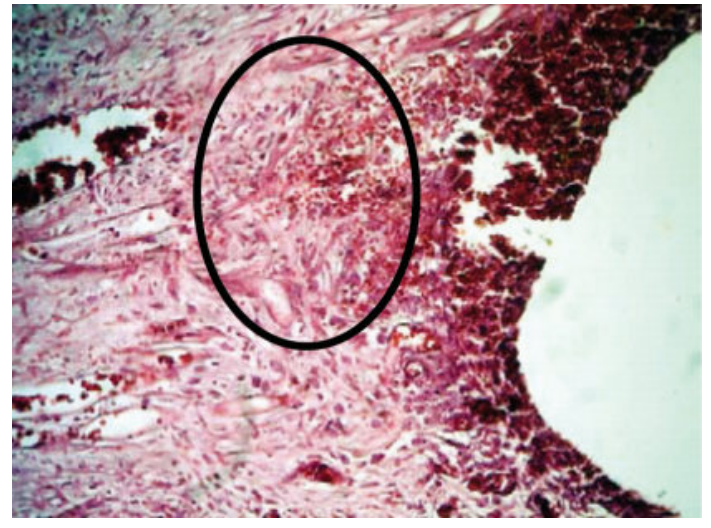

Figure 1. Inflammation cell $\mathrm{O}$

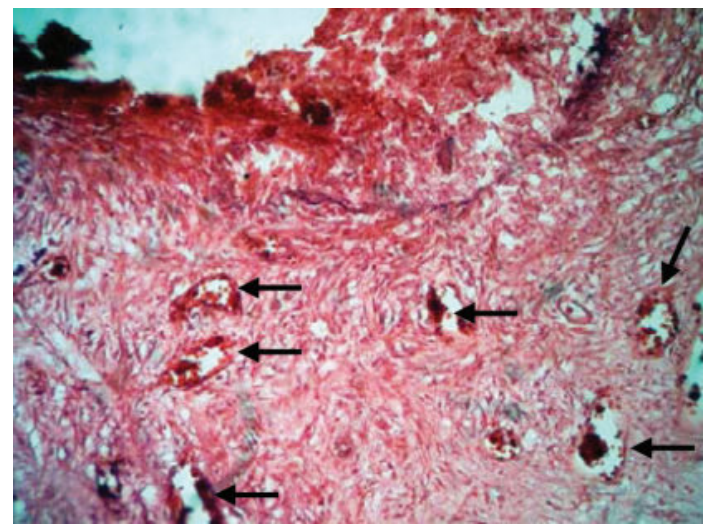

Figure 2. Angiogenesis $(\longleftarrow)$

\section{RESULT}

ANOVA test was performed to know the different response between inflammation cell and angiogenesis in $\mathrm{Ca}(\mathrm{OH})_{2}$ and TGF- $\beta 1$. The result showed significant difference $(\mathrm{p}<0.05)$ in control group, followed by LSD test to know the difference in the period of 7-14 days, 14-21 days, and 7-21 days (Table 2).

Table 1. The mean and standard deviation of inflammation in control group of $\mathrm{Ca}(\mathrm{OH})_{2}$ and TGF- $\beta 1$ on day 7,14 , and 21

\begin{tabular}{cccccccc}
\hline \multirow{2}{*}{ Variable } & \multirow{2}{*}{ Material } & \multicolumn{2}{c}{7 days } & \multicolumn{2}{c}{14 days } & \multicolumn{2}{c}{21 days } \\
\cline { 3 - 8 } & & Mean & SD & Mean & SD & Mean & SD \\
\hline \multirow{2}{*}{ Inflammation } & $\mathrm{Ca}(\mathrm{OH})_{2}$ & 19.3750 & 6.2321 & 19.1250 & 4.1897 & 16.5000 & 4.5981 \\
& $\mathrm{TGF}-\beta 1$ & 21.6250 & 3.8522 & 19.8750 & 3.0909 & 18.5000 & 2.0000 \\
\hline \multirow{2}{*}{ Angiogenesis } & $\mathrm{Ca}(\mathrm{OH})_{2}$ & 24.3750 & 1.7678 & 20.1250 & 2.7484 & 17.8750 & 7.0191 \\
& $\mathrm{TGF}-\beta 1$ & 16.6250 & 4.6579 & 12.8750 & 4.7461 & 12.3750 & 3.3354 \\
\hline
\end{tabular}

SD: Standar deviation 
Table 2. LSD-test on inflammation cell and angiogenesis and $\mathrm{Ca}(\mathrm{OH})_{2}$ and $\mathrm{TGF}-\beta 1$ in the period 7-14 days, 14-21 days, and 7-21 days

\begin{tabular}{lccc}
\hline \multirow{2}{*}{ Variable } & \multirow{2}{*}{\begin{tabular}{c} 
Period of \\
\cline { 3 - 4 }
\end{tabular}} & \multicolumn{2}{c}{ Observation } \\
\cline { 3 - 4 } & & $\mathrm{Ca}(\mathrm{OH})_{2}$ & TGF- $\beta 1$ \\
\hline Inflammation cell & 7-14 days & 0.923 & 0.268 \\
& 7-21 days & 0.271 & 0.055 \\
& $14-21$ days & 0.313 & 0.382 \\
\hline Angiogenesis & $7-14$ days & $0.009 *$ & 0.096 \\
& $7-21$ days & 0.093 & 0.061 \\
& $14-21$ days & 0.785 & 0.818 \\
\hline
\end{tabular}

$*$ = Significant difference

$\mathrm{p}$ of $\mathrm{Ca}(\mathrm{OH})_{2}$ group showed significant difference in angiogenesis in comparison period of 7-14 days. The result of t-Test between $\mathrm{Ca}(\mathrm{OH})_{2}$ and TGF- $\beta 1$ on day 7,14 and 21 showed significant different in angiogenesis on day 7 and 14 (Table 3).

Table 3. t-Test inflammation cell and angiogenesis comparison of $\mathrm{Ca}(\mathrm{OH})_{2}$ and TGF- $\beta 1$ among of 7 days, 14 days and 21 days

\begin{tabular}{lllc}
\hline \multirow{2}{*}{ Variable } & \multicolumn{3}{c}{$\mathrm{p}$ value } \\
\cline { 2 - 4 } & \multicolumn{3}{c}{$\mathrm{Ca}(\mathrm{OH})_{2}$ and TGF- $\beta 1$} \\
\cline { 2 - 4 } & \multicolumn{1}{c}{7 days } & 14 days & 21 days \\
\hline Inflammation cell & 0.400 & 0.690 & 0.287 \\
Angiogenesis & $0.001^{*}$ & $0.002^{*}$ & 0.073 \\
\hline
\end{tabular}

* = significant difference

\section{DISCUSSION}

In this study, there was no significant difference in infiltration of inflammation cell between $\mathrm{Ca}(\mathrm{OH})_{2}$ and TGF- $\beta 1$ on day 7,14 , and 21 , however the mean showed that TGF- $\beta 1$ was higher comparing to $\mathrm{Ca}(\mathrm{OH})_{2}$ due to potential proinflammation character TGF- $\beta 1$ such as: affecting Leukocyte in the initial response of inflammation and strengthening inflammation response in low concentration by stimulating integrin expression, in addition, initiating chemotaxis process as well as increasing extravasation by enhancing useful enzyme in extravasation process. The concentration of TGF- $\beta 1$ increased during inflammation process, by adding exogenic TGF- $\beta 1$, thus, the concentration would be higher, monocyte/macrophage and lymphocyte would be activated by TGF- $\beta 1$ to remove the pathogen. TGF- $\beta 1$ has the most potential role in inflammation and immune response among TGF- $\beta 1$ isoform. Foreign molecules, tissue debris and accumulative leukocyte are no longer necessary prior to pathogen removal. Subsequently the number of plasmin production would also lower and the concentration of TGF- $\beta 1^{5}$ would be similar.

In this study, the observation on day 7 and 14 showed significant difference in angiogenesis. The mean of TGF- $\beta 1$ was lower compared to the mean $\mathrm{Ca}(\mathrm{OH})_{2}$ due to the presence of angiogenesis/neovascularization prior to day 7 in TGF- $\beta 1$ group. The initial recovery started on day $3^{\text {rd }}$ prior to injury meanwhile the granulation tissue is completely vascular. Capillary new blood vessel would penetrate into necrotic tissue in which inflammatory exudates is eradicated by macrophage. Observation on day 7 showed the presence of collagen synthesis type I and simultaneously showed the decrease of capillary blood vessel. The proceeding recovery process would be followed by decrease of ratio between vascular tissue and fibroblast tissue and subsequently collagen production would elevate. ${ }^{9}$ TGF- $\beta 1$ is one of the growth factors which would influence angiogenesis activity and it is important for vascular maturization and remodelling. ${ }^{10} \mathrm{TGF}-\beta 1$ not only increase fibrous tissue deposition, migration of fibroblast proliferation but also collagen synthesis.

Based on the above explanation it is concluded that angiogenesis decrease before day 7 in TGF- $\beta 1$ group compared to $\mathrm{Ca}(\mathrm{OH})_{2}$ in which angiogenesis is higher. In the comparison between both materials the increase of inflammation cell is not present.

\section{REFERENCES}

1. Werner S, Grose R. Regulation of wound healing by growth factors and cytokines. Physiol Rev 2003; 83:835-70.

2. Trope M, Chivian N, Sigurdsson A. Traumatic injuries. In: Cohen S, Burns RC, editors. Pathways of the pulp. $8^{\text {th }}$ ed. St Louis: Mosby Inc; 2002. p. 560-72.

3. Hu CC, Zhang C, Qian Q, Tatum NB. Reparative dentin formation in rat molars after direct pulp capping with growth factors. J Endod 1998; 24:744-51.

4. Arenberg DA, Strieter RM. Angiogenesis. In: Gallin JI, Snyderman $\mathrm{R}$, eds. Inflammation basic principles and clinical correlates. $3^{\text {rd }}$ ed. Philadelphia: Lippincott Williams \& Wilkins; 1999. p. 851-53.

5. Wahl SM. Transforming Growth Factor- $\beta$ (TGF- $\beta$ ) in the resolution and repair of inflammation. In: Gallin JI, Snyderman R, eds. Inflammation basic principles and clinical correlates. $3^{\text {rd }}$ ed. Philadelphia: Lippincott Williams \& Wilkins; 1999. p. 837-42.

6. About I, Bottero MJ, de Denato P, Camps J. Human dentin production in vitro. Exp Cell Res 2000; 258:33-41.

7. Murray PE, Windsor LJ. Analysis of pulpal reactions to restorative procedures, material, pulp capping, and future therapy. Crit Rev Oral Biol Med 2002; 13:509-20.

8. Kunarti S. Stimulasi aktivitas fibroblas pulpa dengan pemberian TGF- $\beta 1$ sebagai bahan perawatan direct pulp capping. Disertasi. 2005. p. 91.

9. McMahon RFT, Sloan P. Inflammation. In: Essentials of pathology for dentistry. $1^{\text {st }}$ ed. Edinburgh: Churchill Livingstone; 2000. p. 26-31.

10. Cotran RS, Kumar V, Collin T. Acute and chronic inflammation. In: Robbins pathologic basis of disease. $6^{\text {th }}$ ed. Philadelphia: WB Saunders Company; 1999. p. 50-111. 